\title{
INTRODUÇÃO
}

\section{AS PROFUNDAS MUDANÇAS INSTITUCIONAIS AO LONGO DA HISTÓRIA DA AGROINDÚSTRIA CANAVIEIRA E OS DESAFIOS ATUAIS}

\author{
Márcia Azanha Ferraz Dias de Moraes
}

A produção de açúcar do Brasil iniciou-se no período colonial, aproximadamente em 1520, - 1 tendo sido o primeiro grande produto de exportação do País. Sua importância para o desenvolvimento do Brasil Colônia é reconhecida por diversos autores. Contudo, ao final do século XIX, a forte concorrência externa ameaçava as exportações nacionais e era necessária a modernização do setor.

No início da década de 1930, a situação da agroindústria canavieira era particularmente vulnerável, devido à grande depressão mundial de 1929 e ao aumento da capacidade agrícola e industrial brasileiras, ocorrido no início da década de 1920. Nestas condições, a intervenção governamental no setor açucareiro, com a criação do Instituto do Açúcar e do Álcool (IAA), em 1933, se instaurou a pedido dos próprios produtores, com o propósito de resolver os problemas de excesso de oferta e de reorganizar os mercados internos.

A cadeia agroindustrial sucroalcooleira certamente foi uma das mais controladas administrativamente pelo Estado brasileiro. Desde a década de 1930, o governo estabelecia a produção (incluindo fixação de cotas de produção de açúcar e de álcool para cada unidade industrial), se encarregava da comercialização dos produtos (ditando os preços da tonelada da cana, do açúcar e dos combustíveis, e determinando os respectivos compradores e vendedores para o álcool combustível), além de ser o responsável por toda a exportação do açúcar e de álcool.

A intervenção estatal incluiu a criação do Proálcool, cuja motivação principal na época de seu lançamento foi reduzir a dependência do País em relação ao petróleo importado, e que possibilitou ao Brasil deter o domínio da tecnologia da produção de álcool, além do desenvolvimento dos carros a álcool (e mais recentemente do carro bicombustível).

Atualmente, o Brasil é internacionalmente reconhecido pelo pioneirismo em desenvolver a produção e uso em larga escala de um combustível renovável, produzido a partir da cana-de-açúcar, com alta eficiência energética e com os menores custos de produção do mundo. 
No que se refere à intervenção do Estado no setor, a partir da segunda metade da década de 1980, iniciou-se na economia brasileira um processo generalizado de desregulamentação, intensificado a partir dos anos 1990, abrangendo a cadeia da cana-de-açúcar. Desde 1999, data da efetiva desregulamentação da agroindústria canavieira, o Estado afastou-se consideravelmente do setor.

A drástica redução da intervenção estatal afetou as relações dos agentes de toda a cadeia produtiva: os produtores de cana-de-açúcar, as usinas e destilarias e as distribuidoras de combustível, além dos consumidores de álcool e açúcar, na medida em que a dinâmica da formação de preços se alterou para a de um livre mercado.

Se, na época da criação do Proálcool, o principal atrativo do uso do álcool combustível foi a redução da dependência em relação ao petróleo importado, atualmente, acrescentam-se os benefícios ambientais ligados às reduções líquidas das emissões de $\mathrm{CO}_{2}$. O fato de ser renovável e menos poluente do que a gasolina tornou o álcool uma alternativa interessante para os países que desejam reduzir suas emissões de carbono, o que pode representar importantes oportunidades para o Brasil, dada sua competitividade e disponibilidade de terras.

Desde a origem da produção de açúcar e álcool até os dias atuais, as mudanças institucionais foram profundas. Citam-se a crise fiscal do Estado brasileiro e seu conseqüente afastamento dos mecanismos de controle da economia do País a partir da década de 1990, associada à passagem de um regime com fortes traços autoritários e burocráticos, que favorecia as decisões centralizadas, para um sistema com características mais democráticas, que fortalece o papel do Congresso; a promulgação da Constituição Federal de 1988, que reforçou o poder do Congresso (que voltou a ser responsável pela aprovação do Orçamento da União) e diminuiu o papel do Estado como interventor na economia brasileira. Portanto, alteraram-se completamente as relações entre Estado e setor privado anteriormente estabelecidas.

Com as mudanças institucionais, muitas das funções previamente exercidas pelo governo passaram a ser de responsabilidade dos diversos segmentos envolvidos na cadeia produtiva da canade-açúcar. A alteração do ambiente institucional trouxe a necessidade de articulação e coordenação entre os agentes da cadeia, significando uma drástica mudança dos papéis até então exercidos, já que, anteriormente, o Estado assumia não só as funções de planejamento e comercialização dos produtos do setor, como também era o mediador dos conflitos que sempre permearam sua história.

É notável o rápido amadurecimento das relações entre os agentes, bem como a implementação de novas formas de gerenciamento das atividades produtivas, além da adoção de instrumentos modernos de comercialização dos produtos.

Porém, ainda existem desafios para serem enfrentados. O ingresso do Brasil na Organização Mundial do Comércio, e suas críticas às políticas protecionistas dos países produtores de açúcar e álcool, ao mesmo tempo em que podem abrir portas às exportações destes produtos, certamente terão como conseqüência um maior questionamento dos nossos principais competidores em relação às questões ambientais e sociais da agroindústria canavieira.

Portanto, nesta nova fase, além da viabilidade econômica, fatores ambientais e sociais ligados à produção são igualmente relevantes. Neste cenário de crescimento e maior inserção no cenário internacional, ressaltam-se os desafios logísticos e a expansão sustentável da produção, incluindose, portanto, os cuidados com o meio ambiente e a preocupação com as questões sociais, de forma a estender os benefícios gerados na cadeia produtiva aos empregados agrícolas e industriais. 
A expectativa com a expansão das exportações, motivada pelo aumento da demanda por energia limpa e renovável, além da expansão do mercado doméstico, aquecido pelo inovador carro bicombustível, significam, em termos macroeconômicos, um expressivo aumento do investimento, além de maior geração de renda e emprego.

Dada a importância desta agroindústria para o futuro da economia brasileira, a Seção de Debates desta edição da revista Economia Aplicada, que discute o setor sucroalcooleiro, deve atrair o interesse de acadêmicos e formuladores de política econômica. Os textos a seguir trazem relevantes contribuições para a literatura, expandindo nosso conhecimento sobre as relações econômicas e sociais da agroindústria canavieira e apontando novas linhas de investigação teóricas e empíricas. 